\title{
MODEL-MODEL PEMBIAYAAN WAKAF TANAH PRODUKTIF
}

\author{
Ahmad Furqon ${ }^{1}$
}

\begin{abstract}
Abstrak
Indonesia memiliki aset wakaf berupa tanah yang sangat besar. Provinsi Jawa Tengah merupakan provinsi yang memiliki aset tanah wakaf terbesar se-Indonesia. Tanah wakaf dapat menjadi faktor pensejabtera masyarakat apabila dikelola secara produktif. Untuk mengelola secara produktif diperlukan pembiayaan atas tanah wakaf tersebut. Karena lembaga wakeaf terkendala ketiadaan dana untuk memproduktifkean aset wakaf tersebut.

Makalab ini bertujuan untuk menjelasakan model-model pembiayaan yang dapat diterapkan dalam pengembangan wakaf tanah produktif, serta mencari model pembiayaan yang paling efektif untuk wakaf tanah produktif. Makalah ini menemukan banyak model pembiayaan yang dapat diterapkan bagi pembiayaan tanah wakaf, akan tetapi pembiayaan yang mengurangi resiko kerugian perlu menjadi pertimbangan lembaga wakaf dalam memilib model pembiayaan tersebut. Pembiayaan yang berbasis partisipasi masyarakat dan pembiayaan dengan akad musyarakah muntahiyah bi tamlik dipandang memiliki resiko yang lebih ringan dibandingkan model pembiayaan lainnya.
\end{abstract}

Keyword : Wakaf tanah

\section{Pendahuluan}

Indonesia memiliki tanah wakaf yang sangat luas. Data dari Subdit Sistem Informasi Wakaf, Kementerian Agama menunjukkan bahwa pada tahun 2012, luas tanah wakaf di Indonesia mencapai 3.492.045.373,754m² yang tersebar di 420.003 lokasi di seluruh wilayah Indonesia. Luas tanah wakaf tersebut hampir lima kali lipat dari keseluruhan negara Singapura ${ }^{2}$.

Tanah wakaf yang sangat luas ini merupakan aset potensial yang menjanjikan keuntungan yang sangat besar apabila dikembangkan secara produktif. Keuntungan dari hasil wakaf tanah tersebut dapat digunakan untuk program kesejahteraan masyarakat, misalnya pengentasan kemiskinan, bantuan pendidikan, bantuan kesehatan, penyediaan rumah murah bagi rakyat yang

${ }^{1}$ Dosen Fakultas Ekonomi dan Bisnis Islam, IAIN Walisongo Semarang

2 Bimas Islam, 2012, Bimas Islam dalam Angka tahun 2012, Jakarta: Bimas Islam, hal. 
tidak mampu. Badan Pusat Statistik Jawa Tengah mencatat jumlah penduduk miskin di Jawa Tengah pada bulan September 2012 mencapai 4,863 juta orang atau 14,98\% dari total penduduk Jawa Tengah ${ }^{3}$. Tanah wakaf di Jawa Tengah yang sangat luas merupakan sleeping giant yang harus dibangunkan karena menjanjikan pemecahan tehadap permasalahan kemiskinan dan permasalahan lain yang dialami oleh provinsi Jawa Tengah. Wakaf dapat menjadi solusi pengurangan angka kemiskinan dan peningkatan kesejahteraan masyarakat.

Melirik wakaf berarti mencari celah untuk memberdayakan aset ekonomi masyarakat. Hal ini disebabkan oleh ketersediaan sarana ekonomi yang terdapat dalam wakaf itu sendiri. Apa yang dimaksud dengan ekonomi disini adalah sisi-sisi finansial material sebagai kebutuhan dasar yang bisa diperoleh melalui pengelolaan dan pengembangan harta wakaf. Berdasarkan asumsi ini, harta wakaf memang harus dikelola secara produktif agar menghasilkan peluang-peluang bagi terbukanya sektor-sektor strategis yang menguntungkan, seperti membuka lapangan kerja baru, pengelolaan pelayanan publik yang meringankan beban ekonomi masyarakat, dan memberikan fasilitas bagi pengembangan usaha ekonomi kecil dan menengah ${ }^{4}$

Pemberdayaan tanah wakaf menjadi wakaf yang produktif dimulai dengan pembiayaan tanah wakaf tersebut. Banyaknya tanah wakaf yang tidak dapat diberdayakan secara produktif diakibatkan oleh ketiadaan dana untuk memberdayakan atau mengelola tanah wakaf tersebut. Pembiayaan menjadi faktor penting dalam pemberdayaan tanah wakaf agar menjadi wakaf yang produktif. Pembiayaan merupakan muqaddimatul wäjib dari pengelolaan atau investasi tanah wakaf, dengan kata lain proses investasi tanah wakaf tanah wakaf menuntut adanya usaha pembiayaan terlebih dahulu atas harta wakaf tersebut.

Menurut Monzer Kahf, para ulama terdahulu telah memikirkan model- model pembiayaan wakaf tanah. Hal ini menunjukkan bahwa pembiayaan merupakan hal penting yang harus dipikirkan nazhir sebelum 2014.

3 Birohumas.jatengprov.go.id/uploads/brs_kemiskinan_1209.33.pdf. diakses tanggal 15 Juli

${ }^{4}$ Dir.Pemberdayaan Wakaf Kemenag RI, 2008, Panduan Pemberdayaan Tanah Wakaf Produktif Strategis di Indonesia, Jakarta: Direktorat Pemberdayaan Wakaf, hal.14. 
melakukan pengelolaan dan pengembangan aset wakaf. ${ }^{5}$ Pada masa sekarang, model-model pembiayaan bertambah banyak, seiring dengan kemunculan lembaga keuangan Islam, sehingga memungkinkan nazhir untuk mengadakan kerjasama dengan lembaga keuangan Islam dalam pembiayaan tanah wakaf, atau dengan menggalang dana dari masyarakat atau publik, dengan model wakaf uang, wakaf saham atau wakaf amal kolektiff.

Keterbatasan dana atau bahkan ketiadaan dana membuat tanah wakaf yang sebenarnya potensial menjadi tidak produktif. Menurut Uswatun Hasanah, salah satu sebab nazhir wakaf tidak bisa memproduktifkan asset wakaf diantaranya adalah ketiadaan dana untuk memproduktifkannya, dimana wakif ketika berwakaf tidak memberikan dana untuk memproduktifkannya. Hingganya menjadi penting menurut penulis untuk mengetahui model- model pembiayaan harta wakaf yang dapat dipakai dalam memproduktifkan tanah wakaf. Kemudian dari beberapa model pembiayaan yang ada, model pembiayaan seperti apakah yang paling efektif untuk diterapkan dalam pemberdayaan wakaf tanah produktif.

Yang dimaksud dengan kata produktif dalam judul makalah ini adalah transformasi dari pengelolaan wakaf yang alami menjadi pengelolaan wakaf yang profesional untuk meningkatkan dan menambah manfaat wakaf?. Menurut Sadono Sukirno, produktif (kata sifat yang berasal dari kata product) diartikan sebagai proses operasi untuk menghasilkan barang dan jasa yang maksimum dengan modal minimum ${ }^{8}$. Dengan demikian wakaf produktif diartikan sebagai proses pengelolaan benda wakaf untuk menghasilkan barang dan jasa yang maksimum dengan modal minimum.

\footnotetext{
5. Kahf, Monzer,2006, al-Waqf al-Islamy, Tathwuruh, Idāratuh, Tanmiyyatuh, Suriah: Dār al-Fikr, hal. 242.

6. Mohammad, Mohammad Tahir Tsabit Haji, 2009, Alternative Development financing Instruments for Waqf Properties, Malaysian Journal of Real Estate, Volume 4 No.2.hal.54, http:/ /www.fksg.utm.my/ cres/goldengate/application/pdf/vol4_no2_4.pdf. diakses tanggal 15 Juli 2014..

7. Mubarok, Jaih, 2008, Wakaf Produktif, Bandung: Simbiosa Rekatama Media, hal.15.

8. Sukirno, Sadono, 1997, Pengantar Teori Mikroekonomi, Jakarta: PT. Raja Grafindo Persada, hal.202.
} 
Model-model Pembiayaan Wakaf Tanah

\section{Pembahasan Model-Model Pembiayaan Wakaf Tanah}

\section{Pengertian Pembiayaan}

Ada beberapa pengertian pembiayaan yang disebutkan oleh beberapa pakar ekonomi Islam, diantaranya pengertian pembiayaanan menurut Syauqi Ahmad Dunya. Pembiayaan menurutnya adalah: "mengeluarkan seluruh sumber daya dan kemampuan untuk mengembangkan modal pokok baik yang bersifat materi mau sumber daya manusia"9. Monzer Kahf mendefinisikan pembiayaan sebagai: "Cover biaya untuk proyek apapun atau proses ekonomi” (Kahf, 2006: 206).

Abdul Qadir ben Azuz mendefinisikan pembiayaan wakaf sebagai: "usaha yang dikeluarkan oleh nazhir baik berupa pemikiran atau perbuatan untuk mendapatkan cover biaya atau biaya untuk menutup kebutuhan proyek investasi wakaf. Atau pembiayaan harta wakaf adalah cara-cara menghasilkan uang, dengan mengfungsikan sumber- sumber keuangan yang dimiliki oleh wakaf atau mencari sumber keuangan luar yang dapat membiayai proses pengembangan proyek- proyek wakaf, sesuai dengan hukum dan Maqāshid Syariab"10.

\section{Ketentuan dalam Pembiayaan Wakaf}

Sebagai instrumen pemberdayaan ekonomi khas Islam, pembiayaan harta wakaf memiliki ketentuan yang tidak terlepas dari prinsipprinsip pokok bermu'amalah dalam Islam, yaitu:

Pertama: Dilarang melakukan pembiayaan untuk harta yang diharamkan atau dilarang melakukan pembiayaan terhadap- proyek- proyek investasi yang diharamkan, walaupun hasil atau keuntungannya dibagikan bagi kemaslahatan bersama atau kemaslahatan kelompok tertentu. Kedua: Dilarang melakukan pembiayaan proyek- proyek investasi dengan uang atau

9. Syauqi Ahmad Dunya,1984, Tamwīl at Tanmiyah fi al-Iqtishād al-Islāmy, Bairut: Muassasah arRisalah, hal. 186.

10., Abdul Qadir Ben Azuz, 2003, Figh Istitsmār al-Waqf wa Tamwīluh fi al-Isläm (Dirāsat Tathbiqiyah 'an al-W aqf al-Jazäir), Disertasi di Universitas al-Jazair, hal.113. 
harta yang haram, seperti hasil penjualan minuman keras, obat- obatan terlarang.

Ketiga, pembiayaan tersebut mewujudkan kemaslahatan, baik yang bersifat primer, sekunder maupun tertier. Pembiayaan harta wakaf harus tunduk pada ketentuan syariah, karena tujuan pembiayaan tidak hanya terbatas pada sekedar mencari untung akan tetapi keuntungan yang diperoleh haruslah sesuai dengan tuntunan syariah ${ }^{11}$.

\section{Model-Model Pembiayaan Wakaf Tanah}

Model-model pembiayaan dalam wakaf telah menjadi perhatian para fuqoha sejak dulu. pendapat fuqoha tentang model-model pembiayaan wakaf dapat ditemukan dalam kitab fiqih karangan mereka atau fatwa-fatwa mereka. Al-Wansyarisy menjelaskan dalam kitabnya bahwa madzab Maliki membolehkan akad al-Musāqät dalam wakaf. Pengarang kitab al-'Atabiyah $f i$ al Fiqh al-Maliki, menyatakan: "Apabila wakaf diperbolehkan wakaf dengan cara menyewakannya atau dengan akad al-muzāra'ah, atau akad al-musāqāt, maka akad- akad tersebut adalah sah dan dapat dimiliki secara sempurna "12.

Monzer Kahf menyebutkan beberap model pembiayaan wakaf yang dipraktekkan oleh ulama terdahulu, dan menyebutnya sebagai model pembiayaan tradisional,yaitu: penambahan wakaf lama dengan wakaf baru, al-Iqtirädh (peminjaman), Ibdāl dan istibdāl (penukaran), Hukr (Sewa Berjangka Panjang dengan Lump Sum Pembayar di Muka yang Besar), alIjäratain (penyewaan dengan dua kali pembayaran) ${ }^{13}$. Model pembiayaan wakaf tanah apabila ditarik garis besarnya tidak terlepas dari tiga prinsip pembiayaan Islam, yaitu: prinsip bagi hasil/ resiko (musyārakah), prinsip jual beli (ba'i) dan prinsip sewa (ijārab) ${ }^{14}$.

Dari tiga prinsip tersebut, muncul beberapa model pembiayaan yang dapat diterapkan dalam pembiayaan wakaf tanah, yaitu:

11. Azuz, 2003:115.

12. Azuz, 2003: 121.

${ }^{13}$ Kahf, 2006:242.

14. Direktorat Pemberdayaan Wakaf Kemenag RI, 2006, Pedoman Pengelolaan dan Pengembangan Wakaf, Jakarta: Direktorat Pemberdayaan Wakaf. , hal.119. 
Model-model Pembiayaan Wakaf Tanah

\subsection{Murābahah}

Muräbahah adalah akad jual beli antara lembaga keuangan dan nasabah atas suatu jenis barang tertentu dengan harga yang disepakati bersama. Lembaga keuangan akan mengadakan barang yang dibutuhkan dan menjualnya kepada nasabah dengan harga setelah ditambah keuntungan yang disepakati ${ }^{15}$.

Dalam pembiayaan wakaf tanah produktif, nazhir dapat melakukan akad muräbahah dengan lembaga keuangan atau bank untuk pembeliaan alat-alat pertanian atau material yang dibutuhkan, seperti pembelian traktor, pupuk, bibit tanaman. Atas pembelian barang tersebut, nazhir membayar harga barang kepada bank dari pendapatan hasil pengembangan harta wakaf dengan cara mencicil.

\subsection{Istishnā'}

Istishnä adalah memesan kepada perusahaan untuk memproduksi barang atau komoditas tertentu untuk pembeli/ pemesan ${ }^{16}$. Menurut Fatwa Dewan Syari'ah Nasional (DSN), Istishna' adalah "akad jual beli dalam bentuk pemesanan pembuatan barang tertentu dengan kriteria dan persyaratan tertentu yang disepakati antara pemesan (pembeli, mustashni') dan penjual (pembuat, shani')".

Dalam aplikasinya, bank syariah melakukan istishnā paralel, yaitu bank (sebagai penerima pesanan. Shäni') menerima pesanan barang dari nasabah (pemesan/ mustashni'), kemudian bank (sebagai pemesan/ mustashni'), memesankan permintaan barang nasabah kepada produsen penjual (shäni) dengan pembayaran di muka, cicil, atau di belakang, dengan jangka wakatu penyerahan yang disepakati bersama ${ }^{17}$.

Model istishnä' memungkinkan pengelola harta wakaf untuk memesan pengembangan harta wakaf yang diperlukan kepada lembaga

15. Riva'I, Veithzal \& Andria Permata Veithzal, 2008, Islamic Financial Management, Teori, Konsep dan Aplikasi Praktis untuk. Lembaga Kenangan, Nasabah, Praktisi dan Mahasiswa, Jakarta: Rajawali

16. Ascarya, 2007, Akad \& Produk Bank Syariah, Jakarta: Rajawali Press, hal.96.

17. Ascarya, hal.98. 
pembiayaan melalui kontrak istishnä'. Lembaga pembiayaan atau bank kemudian membuat kontrak dengan kontraktor untuk memenuhi pesanan pengelola harta wakaf atas nama lembaga pembiayaan tersebut.

Dengan kontrak istishnä' nazhir wakaf dapat memesan kepada lembaga pembiayaan/ bank, pembangunan bentuk- bentuk produktif dari tanah wakaf yang dimilikinya, seperti pembangunan perumahan, hotel, ruko. Kemudian lembaga pembiayaan melakukan kontrak dengan kontraktor untuk pembangunan sesuai dengan keinginan nazhir .

\subsection{Ijārah}

Ijärah didefinisikan sebagai "hak untuk memanfaatkan barang/ jasa dengan membayar imbalan tertentu"18. Menurut Fatwa DSN MUI No.55 tahun 2001, Ijärah adalah "akad pemindahan hak guna (manfaat) atas suatu barang atau jasa dalam waktu tertentu melalui pembayaran sewa/ upah, tanpa diikuti dengan pemindahan kepemilikan barang itu sendiri”'.

Ada dua jenis ijärah dalam hukum Islam, yaitu:

1) Ijärah yang berhubungan dengan sewa jasa, yaitu memperkerjakan jasa seseorang dengan upah sebagai imbalan jasa yang disewa. Pihak yang memperkerjakan disebut musta jir, pihak pekerja disebut ajī, upah yang dibayarkan disebut ujrah.

2) Ijärah yang berhubungan dengan sewa aset atau properti, yaitu memindahkan hak untuk memakai dari aset atau properti tertentu kepada orang lain dengan imbalan biaya sewa. Bentuk ijärah ini mirip dengan leasing (sewa) dibisnis konvensional. Pihak yang menyewa (lesse) disebut musta jir, pihak yang menyewakan (lessor) disebut mu’jir/ muajir, sedangkan biaya sewa disebut ujrah. Ijärah bentuk pertama banyak diterapkan dalam pelayanan jasa perbankan

18. Veithzal Riva'i \& Andria Permata Veithzal, 2008, Islamic Financial Management, Teori, Konsep dan Aplikasi Praktis untuk Lembaga Keuangan, Nasabah, Praktisi dan Mahasiswa, Jakarta: Rajawali Press. 
syari'ah. Sementara itu, jjärah bentuk kedua biasa dipakai sebagai bentuk investasi atau pembiayaan di perbankan Syari'ah ${ }^{19}$.

Dalam penerapan model pembiayaan ijärah terhadap tanah wakaf adalah nazhir memberikan izin kepada financer (penyedia dana) untuk mendirikan sebuah gedung diatas tanah wakaf. Kemudian nazhir menyewakan gedung tersebut untuk jangka waktu yang sama dimana pada periode tersebut dimiliki oleh penyedia dana, dan digunakan untuk tujuan wakaf. Gedung tersebut bisa berupa rumah sakit, sekolah, perkantoran, pusat bisnis, atau apartemen. Nazhir menjalankan manajemen dan membayar sewa secara periodik kepada penyedia dana sesuai dengan biaya sewa yang telah ditetapkan sehingga menutup modal pokok dan keuntungan yang dikehendaki oleh penyedia dana. Apabila masa pembayaran sewa telah selesai maka kepemilikan bangunan tersebut berpindah milik dari penyedia dana kepada nazhir wakaf tanah tersebut ${ }^{20}$

\section{4 . Mudhārabah}

Mudhärabah atau penanaman modal adalah penyerahan modal uang kepada orang yang berniaga sehingga mendapatkan prosentase keuntungan. Mudhārabah merupakan akad bagi hasil ketika pemilik dana/ modal (pemodal), biasa disebut shäbibul mäl rabbul māl, menyediakan modal 100\% kepada pengusaha sebagai pengelola, yang biasa disebut mudhärib, untuk melakukan aktivitas produktif dengan syarat bahwa keuntungan yang dihasilkan akan dibagi diantara mereka berdasarkan kesepakatan yang telah disetujui sebelumnya.

Apabila terjadi kerugian karena proses normal dari usaha, dan bukan karena kelalaian atau kecurangan pengelola, kerugian ditanggung sepenuhnya oleh pemilik modal, sedangkan pengelola kehilangan tenaga dan keahlian yang telah dicurahkannya. Apabila terjadi kerugian karena

19. Ascarya, hal.99.

20. Direktorat Pemberdayaan Wakaf, 2008, Model Pengembangan Wakaf Produktif, Jakarta: Direktorat Pemberdayaan Wakaf, hal.82. 
kecurangan atau kelalaian pengelola, maka pengelola bertanggung jawab sepenuhnya ${ }^{21}$.

Ada dua jenis mudhärabah yang dapat diterapkan dalam pembiayaan wakaf tanah, yaitu: (1) mudhärabah berbasis aset, dan (2) mudhärabah berbasis modal uang.

(1) mudhārabah berbasis aset. Pengelola wakaf dapat mempersilakan penyedia dana untuk membangun gedung diatas tanah wakaf. Gedung yang telah dibangun kemudian disewakan kepada pihak ketiga. Hasil dari penyewaan tersebut dibagi dua antara pengelola wakaf dan penyedia dana. Pengelola wakaf harus membagi keuntungan yang diperolehnya pada dua hal, yaitu untuk meningkatkan saham kepemilikkannya pada gedung tersebut dan untuk pihak penerima manfaat wakaf (manqüf'alaib)..

(2) mudhārabah berbasis modal kapital. Menurut Monzer Kahf, Model mudhārabah dapat digunakan apabila nazhir memposisikan dirinya sebagai pengusaha. Ia dapat menerima bantuan dana cair dari institusi keuangan untuk membangun gedung diatas tanah wakaf. Pengelola wakaf berada ditangan nazhir dan rasio bagi hasil dapat ditentukan berdasarkan pertimbangan usaha yang telah dilakukan oleh pengelola dan kepemilikkan tanah wakaf yang digunakan ${ }^{22}$.

\subsection{Musyārakah}

Musyärakah merupakan istilah yang sering dipakai dalam konteks skim pembiayaan Syariah. Karakteristik dari akad ini adanya keinginan dari para pihak (dua pihak atau lebih) melakukan kerja sama untuk suatu usaha tertentu. Masing- masing menyertakan dan menyetorkan modalnya (baik intangible aset maupun tangible aset) dengan pembagian keuntungan dikemudian hari sesuai kesepakatan. Kepesertaan setiap pihak yang melakukan kerja sama dapat berupa dana (funding), keahlian (skill), kepemilikan (property), peralatan (equipment), barang perdagangan

21. Ascarya, hal.60.

${ }^{22} \mathrm{Kahf}$, hal.16. 
Model-model Pembiayaan Wakaf Tanah

(trading asets), atau intangible aset seperti good will atau hak paten, reputasi/ nama baik, kepercayaan, serta barang- barang lain yang dapat dinilai dengan uang. Lembaga keuangan menyediakan fasilitas pembiayaan dengan cara menyuntikkan modal berupa dana segar agar usaha yang dikelola nazhir dapat berkembang kearah yang lebih baik ${ }^{23}$.

Istilah musyärakah berkonotasi lebih terbatas dari pada istilah syirkah yang lebih umum digunakan dalam fikih Islam. Syirkah berarti sharing "berbagi", dan di dalam terminologi fikih Islam dibagi dalam dua jenis:

a) Syirkah al-Milk atau syirkah amlak atau syirkah kepemilikan, yaitu kepemilikan bersama dua pihak atau lebih dari suatu properti; dan

b) Syirkah al-'aqd atau syirkah uqūd atau syirkah akad, yang berarti kemitraan terjadi karena adanya kontrak bersama, atau usaha komersial bersama ${ }^{24}$.

Konsep musyärakah diusulkan pertama kali oleh tim kerja bentukan Islamic Development Bank (IDB) yang ditugaskan untuk pengembangan wakaf tanah. lembaga wakaf dan bank dapat berkontribusi dalam pengembangan wakaf tanah dengan melakukan kerjasama. Bentuk kerjasamanya adalah lembaga wakaf mengajukan permohonan pembiayaan kepada bank. Sumbangan biaya wakaf dapat dihasilkan dari (a) harga tanah wakaf; dan (b) harga tanah dan sumbangan dari sektor lain. Bank menyediakan biaya pembangunan gedung. Apabila lembaga wakaf hanya mneyediakan tanah saja, maka keuntungan dibagi menjadi dua: pertama, untuk mengembalikan dana dari bank, kedua, dibagi antar lembaga wakaf dan bank sebagai keuntungan dari pengelolaan wakaf tanah tersebut ${ }^{25}$.

Bentuk lain dari model pembiayaan berbasis musyarah adalah musyarakah muntahiyah bi tamlik, adapun gambarannya adalah: misalnnya nazhir wakaf melakukan akad kerjasama dengan lembaga pembiayaan

23 . Riva'I, hal.45.

24. Ascarya, 49.

25 Mohammad Tahir Tsabit Haji, 2009, Alternative Development financing Instruments for Waqf Properties, Malaysian Journal of Real Estate, Volume 4 No.2.hal.16, http://www.fksg.utm.my Lcres/goldengate/application/pdf/vol4 no2 4.pdf. diakses tanggal 15 Juli 2014. 
atau bank Islam dibidang investasi hotel pariwisata. Nazhir menjadikan tanah wakaf yang dikelolanya sebagai modal kerjasama tersebut sedangkan pihak yang menjadi patner kerjasama berkontribusi dalam bentuk mengerjakan pembangunan proyek tersebut. waktu kerjasama disepakati oleh kedua pihak termasuk syarat kebolehan bagi nazhir wakaf untuk membeli bagian dari patner kerjasama apabila ia ingin menjualnya pada saat akad berjalan atau setelah akad selesai26.

\subsection{Model Pembiayaan Musāqāt \& Muzāra'ah}

Model pembiayaan Musāqāt \& Muzāara'ah digunakan untuk tanah wakaf yang digunakan untuk bercocok tanah seperti sawah, kebun maupun ladang. Musāqāt adalah kerjasama dalam perawatan tanaman dengan imbalan bagian yang dari hasil yang diperoleh dari tanaman tersebut. perawatan disini mencakup mengairi (ini merupakan arti sebenarnnya dari Musāqāt, menyiangi dan usaha lain yang berhubungan dengan buahnya ${ }^{27}$

Model pembiayaan Musāqāt ini juga merupakan model investasi dari tanah wakaf tersebut. salah satu bentuknya adalah nazhir melakukan kerjasama dengan pihak lain yang bersedia untuk melakukan perawatan tanaman yang ada diatas tanah wakaf dengan menggunakan peralatan yang dimilikinya. Pihak yang menjadi patner nazhir tersebut akan mendapatkan bayaran atas kerjanya dari hasil penjualan tanaman tersebut ${ }^{28}$.

Muг̄àra'ah adalah kerjasama pengolahan pertanian antara pemilik lahan dan penggarap, dimana pemilik lahan memberikan lahan pertanian kepada penggarap untuk ditanami dan dipelihara dengan imbalan bagian tertentu (prosentase) dari hasil panen. Muzāa'a'ah sering disamakan arti dengan mukhābarah, sebenarnya diantara keduanya terdapat perbedaan terkait dengan benih tanaman, dalam mu₹āra'ah,

\footnotetext{
26 Azuz, hal. 154.

27 .Amir Syarifuddin, 2003, Garis- Garis Besar Fiqih, Jakarta: Prenada Media, hal.242.

28 Azuz, hal.168.
} 
Model-model Pembiayaan Wakaf Tanah

benih berasal dari pemilik lahan, sedangkan mukhābarah, benih berasal dari penggarap lahan pertanian ${ }^{29}$

Dalam perwakafan tanah, model pembiayaan dan investasi dengan menggunakan prinsip Muহāra'ah ini dapat diterapkan, salah satu bentuk penerapannya adalah nazhir wakaf tanah melakukan kerjasama dengan perusahaan yang bergerak dibidang pengolahan tanah pertanian. Nazhir menyerahkan tanah wakaf dan sebagian bibit tanaman kepada perusahaan tersebut untuk dikelola sedangkan perusahaan menyiapkan sebagian bibit dan alat pertanian. Perusahaan melakukan pengolahan lahan pertanian mulai dari tahapan menanam hingga panen. Hasil dari pertanian tersebut dibagi dua sesuai dengan kesepakatan saat akad ${ }^{30}$. Kerjasama dengan model Muzāra'ah ini dapat melibatkan pihak ketiga, dengan ketentuan, pihak nazhir menyediakan tanah pertanian, pihak kedua menyediakan bibit dan alat pertanian dan pihak ketiga melakukan pengolahan lahan pertanian tersebut. hasil dari pertanian tersebut dibagi tiga diantara mereka.

\subsection{Sukuk/ Obligasi Syariah}

Sukuk atau obligasi syariah adalah surat berharga sebagai instrumen investasi yang diterbitkan berdasarkan suatu transaksi atau akad syariah yang melandasinya (underlying transaction), yang dapat berupa ijärah, mudhārabah, musyārakah atau yang lainnya ${ }^{31}$. Fatwa DSN No.32 tahun 2002 menyatakan bahwa Obligasi Syariah adalah: "suatu surat berharga jangka panjang berdasarkan prinsip syariah yang dikeluarkan emiten kepada pemegang obligasi syariah yang mewajibkan emiten untuk membayar pendapatan kepada pemegang obligasi syariah berupa bagihasil/ margin/ fee serta membayar kembali dana obligasi pada saat jatuh tempo”.

29 . Riva'I, 2008, hal.47.

30. Azuz, 2003, hal.186

31. Nurul Huda \& Mustafa Edwin Nasution, 2008, Investasi Pada Pasar Modal Syariah, Jakarta: Kencana Prenada Media Group, hal. 139. 
Ada beberapa macam jenis sukuk berdasarkan bentuk syariah sebagai kontrak atau sub kontrak utama, yaitu: Sanadat al-muqāradha atau sukuk mudhärabah, sukuk musyärakah, sukuk ijärah, sukuk istishnä', sukuk salam/ sekuritas, dan sukuk muräbahah.

Adapun gambaran penerapan sukuk dalam pembiayaan wakat tanah, misalnya dengan menggunakan sukuk mudärabah atau muqāradhah dan sukuk ijärah. Dalam sukuk mudhärabah, nazhir menawarkan sertifikat senilai modal pokok investasi pada proyek wakaf tanah tersebut yang telah dibagi- bagi dalam nominal- nominal kecil. Bagi investor yang berminat menanamkan modalnya maka ia akan mendapatkan sertifikat tersebut, sesuai dengan banyaknya modal yang ditanamkannya. Dalam sertifikat tersebut telah tertera nama investor, nominal modal yang ditanamkan, masa kepemilikan dan peruntukkannya. Dana yang terkumpul dipergunakan pada proyekproyek wakaf tanah produktif. Keuntungan dan kerugian yang diperoleh, dibagi dengan pemilik modal sesuai dengan porsinya dan periode pembagian keuntungan berlangsung sampai habis masa kerjasama tersebut ${ }^{32}$.

Adapun gambaran penerapan sukuk ijärah dalam pembiayaan wakaf tanah adalah nazhir menerbitkan sertifikat penyewaan tanah wakaf dan menjualnya kepada publik dalam sertifikat tersebut tercantum pernyataan investor mewakilkan kepada nazhir untuk membangun gedung yang telah ditentukan dengan biaya yang telah disepakati. Sertifikat juga mencantumkan pernyataan untuk penyewaan bangunan tersebut dengan biaya sewa yang telah ditentukan dan waktu pembayaran yang telah ditentukan pula. Pengelola selanjutnya membayar biaya sewa yang didapatkan dari keuntungan penyewaan kepada investor/ pemilik modal sesuai dengan nominal dan waktu pelunasan yang telah ditetapkan ${ }^{33}$

32 Mohammad, 2006, hal.86.

3333 Kahf, hal.54 


\subsection{Wakaf Saham}

Saham merupakan bukti kepemilikan atas sebuah perusahaan yang melakukan penawaran umum (go public) dalam nominal ataupun persentase tertentu ${ }^{34}$. Yang dimaksud dengan wakaf saham ini adalah keinginan wakif untuk mewakafkan seluruh atau sebagian saham yang dimilikinya dan hasil dari saham tersebut didistribusikan untuk wakaf umum, khusus atau wakaf keluarga, diantaranya untuk pembiayaan wakaf tanah produktif.

Model wakaf saham ini telah dipraktekkan oleh perusahaan bisnis di Malaysia, yaitu Johor Corporation, dengan mewakafkan saham miliknya yang tersebar di Tiram Travel, KPJ Health Care, Kulim, Johor Land, sebesar 100 Juta Ringgit dari nilai saham- saham yang dimilikinya ${ }^{35}$.

\subsection{Sumbangan}

Sumbangan atau infak adalah sumbangan berbentuk uang atau benda berharga untuk membantu yang membutuhkan dengan imbalan pahala akhirat. Ada beberapa bentuk sumbangan, yaitu:

a. Infak, yaitu harta yang dikeluarkan seseorang untuk membantu kebutuhan keluarganya.

b. Zakat, yaitu mengeluarkan harta tertentu yang telah mencapai nishab kepada yang berhak menerimanya apabila telah menjadi milik pribadi dan dimiliki minimal 1 (satu) tahun.

c. Sedekah, yaitu harta yang diberikan kepada orang fakir miskin karena mengharap keredhaan Allah SWT.

${ }^{34}$ Huda, 2008:60.

35 . Masyitha binti Mahmud \& Syamsiah binti Muhammad, waqf al-Ashum wa ash-Shukük wa alHuqūq al-Ma'nawiyah wa al-Manäfi', Majma' Fiqih al-Islāmy OKI, ad-Daurah at-Tāsi'ah 'Asyar, Daulah al-Imārāt al-Arabiyah al-Muttahidah, hal. 3 
d. Al-Qard al-Hasan (Pinjaman Kebajikan), yaitu suatu akad pinjam meminjam dengan ketentuan pihak yang menerima pinjaman tidak wajib mengembalikan dana apabila terjadi force major ${ }^{36}$.

\subsection{Wakaf Uang}

Model pembiayaan tanah wakaf produktif lainnya adalah dengan model wakaf uang. Wakaf uang menurut Fatwa MUI adalah: "wakaf yang dilakukan oleh seseorang atau badan hukum dalam bentuk uang tunai. Termasuk dalam uang adalah surat- surat berharga".

Dana wakaf yang berupa uang dapat diinvestasikan pada asetaset finansial (financial aset) dan pada aset- aset riil (real aset). Investasi pada aset- aset finansial dilakukan di pasar modal misalnya berupa saham, obligasi, warran dan opsi. Sedangkan investasi pada sektor riil dapat berbentuk antara lain pembelian aset produktif, pendirian pabrik, pembukaan pertambangan dan perkebunan ${ }^{37}$

Adapun gambaran pembiayaan wakaf tanah dengan wakaf uang adalah: nazhir bekerjasama dengan LKS-PWU menggalang wakaf uang. Bagi para wakif akan menerima sertifikat wakaf uang yang telah tertera peruntukkan wakaf uang tersebut, misalnya untuk membangun sekolah, rumah sakit, apartemen diatas tanah wakaf, dan juga telah tertera penerima wakaf tersebut bagi keluarga wakif, anak yatim, orang miskin. Hal tersebut seperti yang dilakukan oleh BWI dalam menggalang dana wakaf uang untuk pembanguan Rumah Sakit Ibu \& Anak (RSIA) di Serang Banten ${ }^{38}$.

\subsection{Wakaf Hak Atas Kekayaan Intelektual (HAKI)}

Hak Atas Kekayaan Intelektual atau Hak Milik Intelektual menurut Pasal 21 PP No.42 tahun 2006 adalah hak atas kebendaan

${ }^{36}$ Pusat Komunikasi Ekonomi Syariah,2008, e-book Kamus Populer Keuangan dan Ekonomi Syariah, Jakarta: PKES Publishing., hal. 74.

37 . Mubarok, 2008:128.

38 . bwi.or.id/index.php/in/berita-mainmenu-109/1110-bwi-segera-selesaikan-pembangunanrsia-serang, diakses tanggal 15 Juli 2014. 
yang diakui oleh hukum atas benda yang tidak berwujud berupa kreasi intelektual.

Hak Milik Intelektual mencakup hak cipta, hak paten, hak merek dagang, dan desain industri ${ }^{39}$. Pasal 21 Peraturan Pemerintah No, 42 Tahun 2006 menjelaskan 7 (tujuh) macam hak atas kekayaan intelektual: (1) hak cipta, (2) hak merek, (3) hak paten, (4) hak desain industri, (5)hak rahasia dagang, (6) hak sirkuit terpadu, (7) hak perlindungan varietas tanaman.

Pembiayaan wakaf tanah dapat diperoleh dari model pembiayaan wakaf HAKI, yaitu apabila wakif yang memiliki HAKI mewakafkan hasil dari HAKI yang dimilikinya untuk pembiayaan wakaf tanah. Apabila dijelaskan dalam bagan maka pembagian model- model pembiayaan tanah wakaf adalah sebagai berikut:

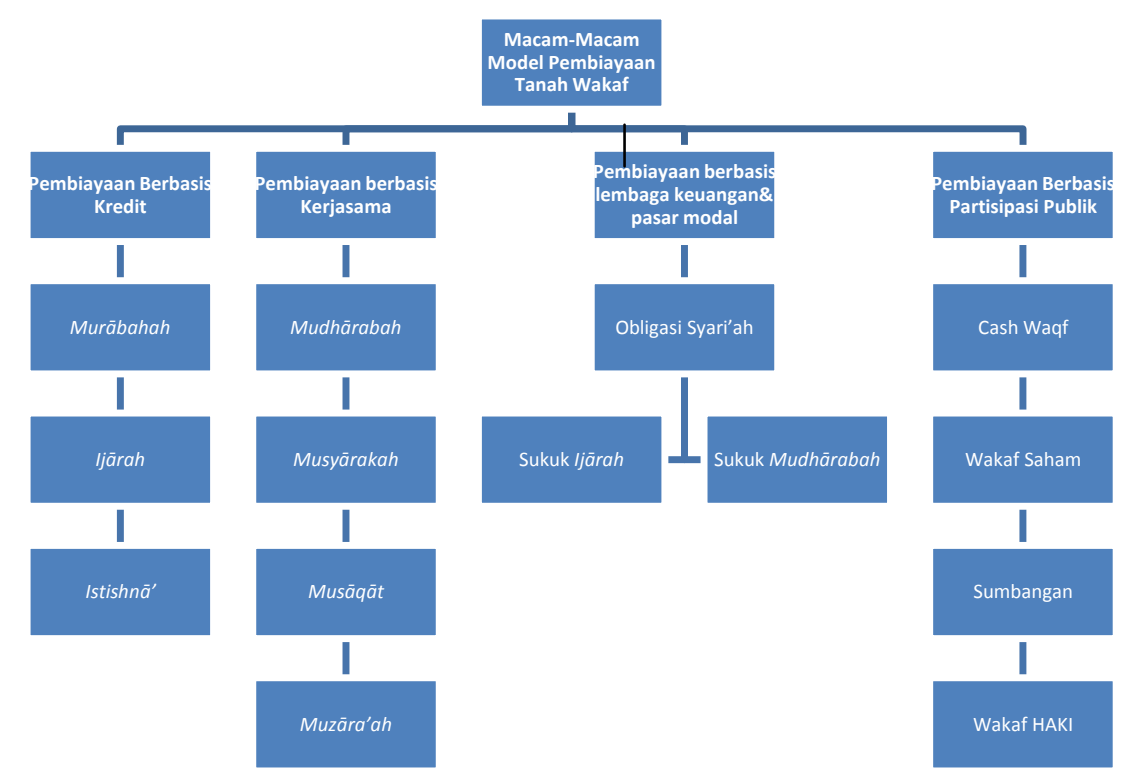

\section{Model Pembiayaan Wakaf yang Ideal}

Apabila membandingkan beberapa model pembiayaan yang ada, menurut pendapat Umar yang paling baik adalah dengan menggunakan Shukuk al-Muqaradhah, karena mengandung metode demokrasi pembiayaan

39 . Fuadi, Munir, 2005, Pengantar Hukum Bisnis: Menata Bisnis Modern di Era Global, Bandung: PT. Citra Aditya Bakti, hal. 203 
dan disalurkan dengan menggunakan model al-Musyarakah al-Muntabiyah bi al-Tamlik, karena pelayanan beban pembiayaan berhubungan dangan pemasukan, bukan dengan hutang sebagaimana model pembiayaan alistishna' atau al-mursahd. sedangkan al-ta'jir al-tamwily dan B.O.T, memiliki permasalahan legalitas, sedangakn al-Hikr memiliki resiko hilangnya tanah wakaf karena lamanya masa peminjaman dan tidak adanya keuntungan yang merugikan penerima wakaf (Umar, 2004:23). Turki bin Muhammad alYahya (2008:3) menawarkan bentuk pembiaya Qardh al-Hasan. Yaitu lembaga wakaf mengajukan pinjaman kepada pelaku bisnis atau pedagang untuk membiayai proyek investasi wakaf tanah, yang telah dilakukan studi kelayakannya oleh lembaga wakaf tersebut. Dengan memberikan jaminan yang cukup terhadap hak pemberi pinjaman dan dana yang dipinjamkan.

Norhaliza dan Mostafa Omer Mohamed memberikan gambaran alternative model pembiayaan yang cocok untuk investasi tanah wakaf, sebagaimana bagan berikut ini:
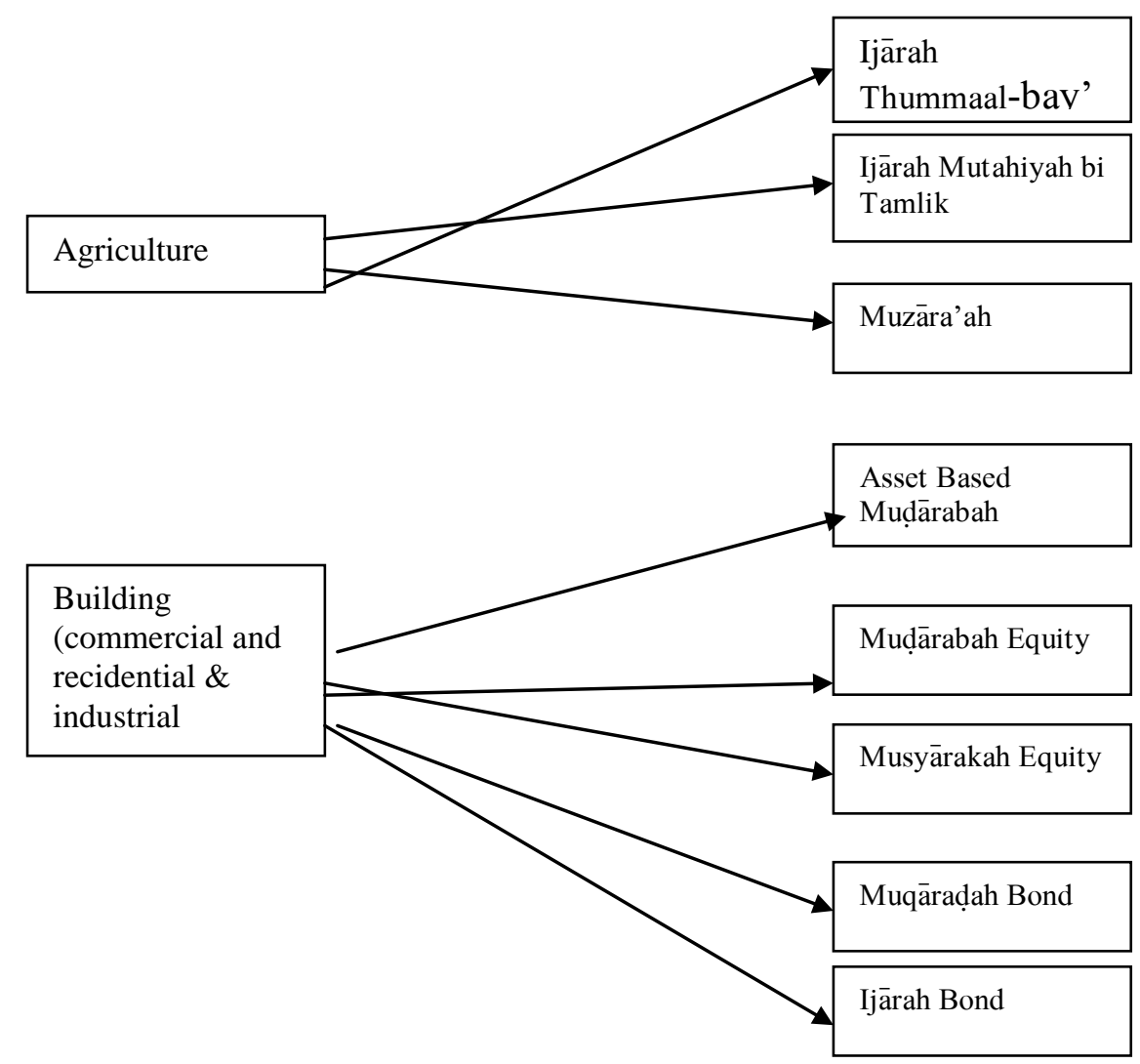

Volume V/Edisi 1/Mei 2014 
Model-model Pembiayaan Wakaf Tanah

\section{Penutup}

Berdasarkan pembahasan di atas, dapat disimpulkan bahwa begitu banyak model-model pembiayaan tanah wakaf yang dapat dilakukan oleh nazhir wakaf untuk membiayai aset wakaf dalam rangka memproduktifkan aset wakaf tersebut. Pembiayaan dengan mengandalkan partisipasi publik dalam bentuk wakaf saham, wakaf uang, infak dan sedekah dapat menjadi pilihan pembiayaan, karena tidak memiliki resiko keharusan mengembalikan. Akan tetapi menuntut kepercayaan dan legitimasi publik terlebih dahulu, sehingga bagi lembaga wakaf baru akan menjadi problem tertentu.

Nazhir dapat juga dengan menggunakan model pembiayaan Sbukuk alMuqaradhah, dengan akad al-Musyarakah al-Muntabiyah bi al-Tamlik. 


\section{DAFTAR PUSTAKA}

Ascarya, 2007, Akad \& Produk Bank Syariah, Jakarta: Rajawali Press.

Ben Azuz, Abdul Qadir, 2003, Fiqh Istitsmār al-Waqf wa Tamwiluh fi al-Isläm (Diräsat Tathbiqiyah 'an al-Waqf al-Jazäir), Disertasi di Universitas alJazair.

Dawwabah, Asyraf Muhammad, 2005, Tashawnur Muqtarah lil Tamwil bi al-W aqf Majalah Awqäf Kuwait, edisi ke-9.

Direktorat Pemberdayaan Wakaf, 2008, Model Pengembangan Wakaf Produktif, Jakarta: Direktorat Pemberdayaan Wakaf.

----------,2008, Panduan Pemberdayaan Tanah Wakaf Produktif Strategis di Indonesia, Jakarta: Direktorat Pemberdayaan Wakaf..

,2006, Pedoman Pengelolaan dan Pengembangan Wakaf, Jakarta: Direktorat Pemberdayaan Wakaf.

----------,2008, Pedoman Pengelolaan Wakaf Tunai, Jakarta: Direktorat Pemberdayaan Wakaf.

Dunya, Ahmad Syauqi,1984, Tamwīl at Tanmiyah fi al-Iqtishād al-Islāmy, Bairut: Muassasah ar-Risalah.

Fuadi, Munir, 2005, Pengantar Hukum Bisnis: Menata Bisnis Modern di Era Global, Bandung: PT. Citra Aditya Bakti.

Hasan, Zulkifli, an Overview of the Effectiveness of the Administration of Waqf Land in Malaysia, zulkiflihasan.files.wordpress.com/2008/.../microsoft-wordjurnal-slr-waqf.pdf. diakses tanggal 2 November 2010.

Huda, Nurul \& Mustafa Edwin Nasution, 2008, Investasi Pada Pasar Modal Syariah, Jakarta: Kencana Prenada Media Group.

Kahf, Monzer,2006, al-Waqf al-Islamy, Tathwuruh, Idāratuh, Tanmiyyatuh, Suriah: Dār al-Fikr.

Masyitha binti Mahmud \& Syamsiah binti Muhammad, waqf al-Ashum wa ashShukūk wa al-Huqūq al-Ma'nawiyah wa al-Manäfi', Majma' Fiqih alIslāmy OKI, ad-Daurah at-Tāsi'ah 'Asyar, Daulah al-Imārāt alArabiyah al-Muttahidah. 
Model-model Pembiayaan Wakaf Tanah

Mohammad, Mohammad Tahir Tsabit Haji, 2009, Alternative Development financing Instruments for Waqf Properties, Malaysian Journal of Real Estate, Volume 4 No.2., http://www.fksg.utm.my/cres/goldengate/ application/pdf/vol4_no2_4.pdf. diakses tanggal 2 November 2010.

--------, 2005, an Ideal Financial Mecanism for Development of the Waqf Properties in Malaysia, Malaysia: Pusat Penelitian Universitas Teknologi Malaysia.

Mohammad, Mohammad Thahir Tsabit Haji, Alternative Development Financing Instruments for Waqf Properties, Malaysian Journal of Real Estate Volume 4 No.2.

Mubarok, Jaih, 2008, Wakaf Produktif, Bandung: Simbiosa Rekatama Media.

Pusat Komunikasi Ekonomi Syariah,2008, e-book Kamus Populer Keuangan dan Ekonomi Syariah, Jakarta: PKES Publishing.

Riva'I, Veithzal \& Andria Permata Veithzal, 2008, Islamic Financial Management, Teori, Konsep dan Aplikasi Praktis untuk Lembaga Keuangan, Nasabab, Praktisi dan Mahasiswa, Jakarta: Rajawali Press.

Sukirno, Sadono, 1997, Pengantar Teori Mikroekonomi, Jakarta: PT. Raja Grafindo Persada.

Syarifuddin, Amir, 2003, Garis- Garis Besar Fiqih, Jakarta: Prenada Media. 